\title{
Vaccination against Paediatric Respiratory Pathogens
}

\author{
Sonia Bianchini ${ }^{1}$, Alberto Argentiero ${ }^{1}$, Barbara Camilloni ${ }^{2} \oplus$, Ettore Silvestri ${ }^{1}$, Anna Alunno ${ }^{2}$ \\ and Susanna Esposito $3, * \mathbb{D}$ \\ 1 Pediatric Clinic, Department of Surgical and Biomedical Sciences, Università degli Studi di Perugia, \\ 06123 Perugia, Italy; Bianchini.sonia@fastwebnet.it (S.B.); aargentiero85@gmail.com (A.A.); \\ ettoresilvestri1981@gmail.com (E.S.) \\ 2 Microbiology Unit, Department of Medicine, Università degli Studi di Perugia, 06123 Perugia, Italy; \\ barbara.camilloni@unipg.it (B.C.); anna.alunno@unipg.it (A.A.) \\ 3 Pietro Barilla Children's Hospital, Department of Medicine and Surgery, University of Parma, \\ 43126 Parma, Italy \\ * Correspondence: susanna.esposito@unimi.it; Tel.: +39-0521-903524
}

Received: 7 August 2019; Accepted: 10 October 2019; Published: 1 November 2019

\begin{abstract}
Acute respiratory infections (ARIs) are extremely common in children, especially those under 5 years old. They can lead to complications, super-infection, respiratory failure, and even compromised respiratory function in adulthood. For some of the responsible pathogens, vaccines are available. This review reports current issues about vaccines against the main respiratory pathogens to highlight the available strategies to reduce the burden of paediatric respiratory disease. The optimal use of influenza, pneumococcal, pertussis and measles vaccines is required in order to reduce ARI burden. Vaccination coverage rates must be improved to achieve the full benefits of these vaccines. Recently, advances in the knowledge of respiratory syncytial virus structural biology and immunology as well as the development of new techniques to generate vaccine candidates have increased the number of promising vaccines even against this harmful pathogen.
\end{abstract}

Keywords: respiratory pathogen; vaccine; children; complication; outbreak; infection

\section{Introduction}

Acute respiratory infections (ARIs) remain one of the most common major public health threats, accounting for millions of episodes of severe acute lower respiratory infections that result in hospital admissions of otherwise healthy infants and young children worldwide [1-7]. One-third of the annual deaths occurring in the world are thought to be due to infectious diseases, and respiratory tract infections are responsible for 4 million deaths worldwide each year [8]. According to estimates made by the World Health Organization (WHO), pneumonia kills more children worldwide than any other disease, even more than acquired immune deficiency syndrome (AIDS), malaria and measles combined [9-11].

In healthy children, nasopharyngeal colonization with respiratory bacteria is a prerequisite for the development of respiratory or invasive (i.e., sepsis, meningitis) diseases [12]. Asymptomatic transient nasopharyngeal colonization with bacteria, such as Streptococcus pneumoniae, Haemophilus influenzae and Staphylococcus aureus, is common and decreases with age and the maturation of the immune system. Geographic region, ethnicity, season, day-care attendance, environmental factors and previous vaccinations are important determinants of bacterial colonization $[13,14]$.

Respiratory viruses including influenza viruses, respiratory syncytial virus (RSV), human rhinoviruses (HRV), human metapneumovirus (HMPV), parainfluenza viruses, adenovirus (ADV) and human bocavirus (BoV) are responsible for approximately 35-87\% of ARIs in children [15-17]. Viral co-infections occur in $4-33 \%$ of children hospitalized with ARIs [18,19]. Bacterial infections 
caused by S. pneumoniae and H. influenzae may commonly be observed in the later stages of respiratory diseases [20]. The incidence of respiratory viral/bacterial co-infection in young children ranges from $1 \%$ to $44 \%$ [21], and studies on influenza pandemics over the last 100 years have strengthened the association of bacterial super-infections and influenza infections [2,22]. In addition, pertussis and measles still represent serious medical issues with lower respiratory tract involvement in several countries.

There has recently been an increase in the number of available vaccines against respiratory pathogens recommended for children and adolescents by the health authorities, and many studies have been performed to evaluate their efficacy, safety and tolerability. The aim of this review is to report current issues about vaccines against some respiratory pathogens to highlight the available strategies to reduce the burden of paediatric respiratory disease.

\section{Respiratory Pathogens and Available Vaccines}

\subsection{Influenza Vaccination}

Influenza is a common disease that causes annual epidemics, leading to medical, social and economic problems $[23,24]$. Together with the elderly population, children under 5 years of age, even in the absence of underlying chronic diseases, have the highest risk of severe disease leading to hospitalization and, although rarely, to death [25]. Influenza is estimated to be the cause of approximately 374,000 hospitalizations of children $<1$ year of age and 870,000 hospitalizations of children $<5$ years of age annually [26-32]. Moreover, children are the most important cause of the spread of the infection in communities because they shed the virus in greater amounts and for longer periods of time than adults [33].

Many studies have demonstrated the risk of superinfection by S. pneumoniae and S. aureus during influenza, with a significant increase in the number of medical visits, drug prescriptions, and hospital admissions for respiratory disease [34-36]. Influenza-related complications seem to be more common in children with underlying chronic severe diseases, which is why health authorities worldwide have long recommended that these children receive the influenza vaccine every year. However, recently collected data clearly demonstrate that otherwise healthy children can also suffer from severe influenza and that the annual number of deaths is not different from that in children with chronic severe diseases [34,35].

Every year during the influenza season, together with the two subtypes of influenza $A$ virus (A/H1N1 and A/H3N2), two lineages of influenza B viruses (B/Victoria/2/87-like and B/Yamagata/16/88-like) simultaneously circulate; in some years, the influenza B viruses are responsible for the major disease burden [37-39]. Unlike influenza A viruses, humans are the sole host with epidemiological relevance for influenza B viruses. Influenza B viruses evolve mainly through genetic reassortment between strains of different lineages. This allows for the escape from host immunity and the preservation of the ability to cause disease. Regardless of the lineage, influenza B infection can cause severe disease and death [39]. During influenza season, influenza $C$ virus can circulate infecting humans, dogs, and pigs, sometimes causing severe illness and local epidemics; however, influenza $\mathrm{C}$ virus is less common than the other types of influenza viruses and usually it only causes mild disease in children.

In the past, recommended vaccines included only one influenza B lineage, chosen by the World Health Organization (WHO) based on surveillance data regarding the lineage that had been observed to dominate in the previous year; however, currently, quadrivalent vaccines containing both influenza B lineages represent the best influenza prevention strategy [40-42]. Studies have shown that the administration of quadrivalent inactivated (IIV) and live attenuated (LAIV) influenza vaccines to healthy children is effective at reducing the total burden of influenza, including preventing severe cases and saving costs due to productivity losses in parents and school absenteeism, with an acceptable level of safety and tolerability [43-45]. 
The USA Advisory Committee on Immunization Practices (ACIP) recommends influenza vaccination for the entire paediatric population, regardless of age and health conditions, starting from a minimum age of 6 months for IIV and a minimum age of 2 years for LAIV vaccines [46,47]. The ACIP highlights the importance of administering 1 dose of any influenza vaccine annually to prevent influenza disease and complications, with 2 doses separated by at least 4 weeks for children 6 months-8 years who did not receive at least 2 doses of influenza vaccine before 1 July 2018 [46]. Within Europe, there are huge variations in influenza vaccine recommendations; for example, in Italy, as in some other countries, the influenza vaccine is recommended only for at-risk people and not healthy children [48].

The need to protect neonates and infants in the first 6 months of life from influenza is so important that many health authorities have recommended influenza vaccinations of pregnant women [49-51]. Studies have shown that vaccination during pregnancy is effective in reducing influenza cases for at least one influenza season $[52,53]$.

Experts agree that the available influenza vaccines can significantly reduce the risk of contracting influenza in healthy or immunocompromised subjects of any age [54]. Preventing influenza infection through vaccination may decrease the subsequent burden of infection by some of the bacterial pathogens, reduce hospitalizations, and reduce antibiotic prescriptions for influenza complications in children and adolescents [55,56]. Moreover, a reduction in influenza cases can have an impact on the abuse of antibiotics that are irrationally prescribed to a large number of paediatric patients with uncomplicated influenza, thus limiting the increase in antimicrobial resistance $[57,58]$.

\subsection{Pneumococcal Vaccination}

S. pneumoniae is a Gram-positive coccus that can survive under both aerobic and anaerobic conditions [59]. It causes mucosal and invasive infections in children and adults, most commonly acute otitis media (AOM), community-acquired pneumonia (CAP), and invasive pneumococcal diseases (IPD), such as bacteraemia and meningitis [60-64].

In the late 1970s, a 14-valent Pneumococcal Polysaccharide Vaccine (PPV) was registered in the United States, containing purified polysaccharides of 14 pneumococcal serotypes $(1,2,3,4,6 \mathrm{~A}, 7 \mathrm{~F}$, $8,9 \mathrm{~N}, 12 \mathrm{~F}, 14,18 \mathrm{C}, 19 \mathrm{~F}, 23 \mathrm{~F}$, and 25F) [65,66]. In 1983, this vaccine was replaced by a 23-valent PPV (PPV23) [66]. However, the polysaccharides pneumococcal vaccines were not effective in younger children and were not able to induce herd immunity.

The first polysaccharide capsular antigen conjugated to a protein (PCV) was PCV7 $(4,6 \mathrm{~B}, 9 \mathrm{~V}, 14$, 18C, 19F, 23F), which was introduced in the United States in 2000 for use in infants. Its introduction in Europe followed in 2001. With the development of PCVs, a new era in the prevention of infections due to $S$. pneumoniae has begun [67]. However, despite being able to significantly reduce pneumococcal disease incidence, the first PCV, the heptavalent preparation (PCV7), quickly exhibited limitations. It was protected against 7 pneumococcal serotypes, considerably fewer than the total number of infective pneumococcal serotypes that circulate [67]. Moreover, the composition of PCV7 was based on serotypes that most commonly caused invasive pneumococcal disease (IPD) in the USA [67]. However, other serotypes isolated more frequently in other countries meant PCV7 could be less effective than expected in some geographic areas. To address these limitations, a few vaccines effective against an increased number of pneumococcal serotypes were developed. Among them, those with 10 and 13 serotypes were licensed for use in humans. Both contained, together with the serotypes already present in PCV7, serotypes 1, 5, and 7F [68,69]; in PCV13 serotypes 3, 6A and 19A were added [68,69]. A great number of studies have shown that both vaccines are immunogenic, safe, well tolerated and very effective because their contribution reduces the risk of pneumococcal diseases in vaccinated children and, increases herd immunity, for the unimmunized [68,69].

Practically, for the prevention of pneumococcal infections in the paediatric population it is generally inferred that PCV10 and PCV13 are similarly effective and that only the cost of vaccine procurement can influence the choice to use one over the other [70]. 


\subsection{Pertussis Vaccination}

Bordetella pertussis is a Gram-negative coccobacillus that causes whooping cough and persistent cough, especially in neonates, school-aged children and adolescents [71,72].

The classic manifestation of the disease can be divided into three phases: (1) nonspecific symptoms, such as coryza, fever, and occasional cough; (2) constant and uncontrollable cough after two weeks, followed by forced inspiration producing a whooping sound; and (3) the convalescence phase, in which symptoms decrease progressively, and complications can appear. Complications, such as pneumonia, are frequent and are responsible for over $90 \%$ of the deaths attributable to the disease in children younger than one year of age $[73,74]$.

There has been an increase in the incidence of pertussis in the European Union from 2011 onwards [75]. The resurgence of pertussis observed in recent years seems to be a complex but real phenomenon due to a number of reasons, including the use of acellular pertussis (aP) vaccines in many locales. Lack of mucosal immune responses after aP vaccine administration favour infection, persistent colonization and transmission of the pathogen. Moreover, earlier waning of protective immunity and the circulation of $B$. pertussis variants depleted of vaccine-included antigens further favor the increase in pertussis disease [74]. Studies in immunized children have reported that antibody responses and protective immunity wane 3-5 years after immunization with acellular pertussis (aP) vaccines, which may reflect poor induction of memory $\mathrm{T}$ and/or B cells [76-78].

The majority of health authorities recommend the administration of 2-3 aP vaccine doses in the first year of life with the administration of booster doses at pre-school age, during adolescence and then every 10 years during adulthood $[79,80]$. Recently, in several countries vaccination against pertussis in the 2nd and 3rd vaccination during pregnancy is recommended in order to prevent pertussis in the first 6 months of life [81,82]. Studies showed $>90 \%$ effectiveness of pertussis vaccination of mothers against pertussis in the first 6 months of life. Vaccine administration in pregnancy is safe for both mother and foetus [81,82].

In conclusion, prevention of pertussis with currently available vaccines reaching high vaccination coverage rates remains a priority, including the vaccination of pregnant women [83]. Several different $\mathrm{aP}$ vaccines are available, but it has yet to be determined which of them confers the highest and the most-prolonged protection. Further studies are needed to evaluate the importance of individual antigens included in aP vaccines in conferring protection against disease, colonization, and transmission. However, present knowledge seems to indicate that pertussis toxin, particularly if genetically detoxified, represents the main antigen that ensures protection from disease even if not from infection. The optimal pertussis vaccine would be one that induces both mucosal and systemic responses similar to those occurring under natural infection, leading to long-term protection against both disease and infection. Such a vaccine might increase public confidence and result in better vaccine uptake.

\subsection{Measles Vaccination}

Measles is an acute viral illness caused by a single-stranded RNA enveloped virus in the family Paramyxoviridae, genus Morbillivirus [84,85]. It is characterized by a prodrome of fever and malaise, cough, coryza, and conjunctivitis, followed by a maculopapular rash. Measles can lead to severe complications, which can deeply impact children, and pneumonia represents one of the most common [84,85]. It is still responsible for more than 100,000 deaths every year $[84,85]$.

Although the measles vaccine was introduced in national vaccination schedules in the majority of the countries 20 years ago, several outbreaks have occurred because of insufficient vaccination coverage in the European Region [86,87]. Every month, despite the availability of the vaccine, many measles cases continue to be reported worldwide, with episodic clusters. In the USA, 880 cases were reported from the beginning of 2019 through May [86]. In Europe, twenty-seven countries reported measles data for March 2019, with 1,548 cases reported by 22 countries [87]. These data highlight the importance of maintaining high vaccination coverage with two doses of measles vaccine administered in the first 
years of life, the necessity of identifying susceptible individuals of any age and considering undertaking catch-up immunization or supplementary immunization activities to close immunity gaps.

\subsection{Respiratory Syncytial Virus (RSV)}

RSV is a single-stranded RNA enveloped virus belonging to the recently named Pneumoviridae family, Orthopneumovirus genus, which causes lower respiratory tract illness [88,89]. Infection does not confer immunity to upper respiratory tract reinfection. The peak of severe disease is among infants in the first 3 months of life [90]. Prematurity, low birth weight, male sex, broncho-pulmonary dysplasia, congenital heart disease, immunodeficiency, cerebral palsy, and Down's syndrome are risk factors for severe RSV bronchiolitis, but 50-80\% of emergency admissions occur in otherwise healthy infants born at term [90]. Worldwide, RSV disease in children under the age of 5 years accounts for an estimated 33.8 million lower respiratory tract infections, 3.4 million hospitalizations, and up to 200,000 deaths annually [90].

Despite a consensus on the need for an RSV vaccine, there is no licensed product available yet, mainly due to the early age of infection, the capacity of RSV to evade innate immunity, and the failure of RSV-induced adaptive immunity to prevent re-infection [91]. Several clinical trials are now ongoing to assess the safety and effectiveness of different RSV vaccine candidates [92,93]. Owing to the substantial burden of RSV disease worldwide, RSV vaccine continues to be a necessity for most infants, children and also the elderly. The ideal vaccine should produce long-lasting immunity characterized by a robust Th1-mediated response and high titers of neutralizing antibodies; furthermore, it should protect against both RSV-A and RSV-B, in the presence of maternal antibodies as well, and avoid vaccine-enhanced disease.

Following the first clinical vaccine trial in the 1960s, significant progress has been made. Improved understanding of RSV immunology and structural biology as well as recent advances in vaccine technology are the bases of some of the successes. There are currently a large number of candidates in the pre-clinical phase or undergoing clinical trials, and we are waiting for the information to become available from these studies. Among the candidates in advanced clinical trials, nanoparticle and subunit vaccines are the most promising for pregnant women and the elderly, whereas live-attenuated, vector-based or subunit vaccines are being considered the paediatric population. Ongoing studies could identify effective candidates. An active instrument against infection is needed since RSV infection can cause serious complications in infants, young children and the elderly.

\section{Conclusions}

ARIs are extremely common in children, especially those under 5 years old. They can lead to complications, super-infection, respiratory failure, and even compromised respiratory function in adulthood. For some of the responsible pathogens, vaccines are available. This review focuses on the most recent data about vaccines against respiratory pathogens. The use of influenza, pneumococcal, pertussis and measles vaccines is essential to reduce ARIs burden. Vaccination coverage rates must be improved to achieve the full benefits of these vaccines. Recently, advances in the knowledge of RSV virus biology and immunology as well as the development of new techniques to generate vaccine candidates are finally increasing the number of promising vaccines against even this harmful pathogen.

Author Contributions: S.B. wrote the first draft of the manuscript; A.A. (Alberto Argentiero), E.S. and A.A. (Anna Alunno) participated in patient management and performed the literature review; B.C. provided scientific contributions; S.E. critically revised the paper and gave her scientific contributions. All of the authors read and approved the final version of the manuscript.

Funding: This review was funded by IMI-JU-2013 grant (Flucop project).

Conflicts of Interest: The authors declare no conflict of interest. 


\section{References}

1. Naz, R.; Gul, A.; Javed, U.; Urooj, A.; Amin, S.; Fatima, Z. Etiology of acute viral respiratory infections common in Pakistan: A review. Rev. Med. Virol. 2019, 29, e2024. [CrossRef] [PubMed]

2. Chen, J.; Hu, P.; Zhou, T.; Zheng, T.; Zhou, L.; Jiang, C.; Pei, X. Epidemiology and clinical characteristics of acute respiratory tract infections among hospitalizedinfants and young children in Chengdu, West China, 2009-2014. BMC Pediatr. 2018, 18, 216. [CrossRef] [PubMed]

3. Shi, T.; McLean, K.; Campbell, H.; Nair, H. Aetiological role of common respiratory viruses in acute lower respiratory infections in children under five years: A systematic review and meta-analysis. J. Glob. Health 2015, 5, 010408. [CrossRef]

4. Nair, H.; Simões, E.A.F.; Rudan, I.; Gessner, B.D.; Azziz-Baumgartner, E.; Zhang, J.S.F.; Daniel, R.M.D.; Mackenzie, G.A.; Moiïsi, G.C.; Roca, A.; et al. Global and regional burden of hospital admissions for severe acute lower respiratory infections in young children in 2010: A systematic analysis. Lancet 2013, 381, 1380-1390. [CrossRef]

5. Nohynek, H.; Madhi, S.; Grijalva, C.G. Childhood bacterial respiratory diseases: Past, present, and future. Pediatr. Infect. Dis. J. 2009, 28, 127-132. [CrossRef]

6. Esposito, S.; Bianchini, S.; Polinori, I.; Principi, N. Impact of OM-85 Given during Two Consecutive Years to Children with a History of Recurrent Respiratory Tract Infections: A Retrospective Study. Int. J. Environ. Res. Public Health 2019, 16, E1065. [CrossRef]

7. Chakhunashvili, G.; Wagner, A.L.; Power, L.E.; Janusz, C.B.; Machablishvili, A.; Karseladze, I.; Olgha, T.M.; Khatuna, Z.; Paata, I.; Gregory, C.G.; et al. Severe Acute Respiratory Infection (SARI) sentinel surveillance in the country of Georgia, 2015-2017. PLoS ONE 2018, 13, e0201497. [CrossRef]

8. Schluger, N.W.; Koppaka, R. Lung disease in a global context. A call for public health action. Ann. Am. Thorac. Soc. 2014, 11, 407-416. [CrossRef]

9. Wardlaw, T.; Salama, P.; Johansson, E.W.; Mason, E. Pneumonia: The leading killer of children. Lancet 2006, 368, 1048-1050. [CrossRef]

10. O’Brien, K.L.; Wolfson, L.J.; Watt, J.P.; Henkle, E.; Deloria-Knoll, M.; McCall, N.; Lee, E.; Mulholland, P.K.; Levine, O.S.; Cherian, T.; et al. Burden of disease caused by Streptococcus pneumoniae in children younger than 5 years: Global estimates. Lancet 2009, 374, 893-902. [CrossRef]

11. Liu, L.; Oza, S.; Hogan, D.; Chu, Y.; Perin, J.; Zhu, J.; Lawn, J.E.; Cousens, S.; Mathers, C.; Black, R.E. Global, regional, and national causes of under-5 mortality in 2000-15: An updated systematic analysis with implications for the sustainable development goals. Lancet 2016, 388, 3027-3035. [CrossRef]

12. Bogaert, D.; De Groot, R.; Hermans, P.W. Streptococcus pneumoniae colonisation: The key to pneumococcal disease. Lancet Infect. Dis. 2004, 4, 144-154. [CrossRef]

13. Nair, H.; Brooks, W.A.; Katz, M.; Roca, A.; Berkley, J.A.; Madhi, S.A.; Simmerman, J.M.; Gordon, A.; Sato, M.; Howie, S.; et al. Global burden of respiratory infections due to seasonal influenza in young children: A systematic review and meta-analysis. Lancet 2011, 378, 1917-1930. [CrossRef]

14. Verhagen, L.M.; Luesink, M.; Warris, A.; de Groot, R.; Hermans, P.W. Bacterial respiratory pathogens in children with inherited immune and airway disorders: Nasopharyngeal carriage and disease risk. Pediatr. Infect. Dis. J. 2013, 32, 399-404. [CrossRef] [PubMed]

15. Doan, Q.; Enarson, P.; Kissoon, N.; Klassen, T.P.; Johnson, D.W. Rapid viral diagnosis for acute febrile respiratory illness in children in the Emergency Department. Cochrane Database Syst. Rev. 2014, 15, 006452. [CrossRef]

16. Bashir, U.; Nisar, N.; Arshad, Y.; Alam, M.M.; Ashraf, A.; Sadia, H.; Kazi, B.M.; Zaidi, S.S. Respiratory syncytial virus and influenza are the key viral pathogens in children $<2$ years hospitalized with bronchiolitis and pneumonia in Islamabad Pakistan. Arch Virol. 2017, 162, 763-773.

17. García-García, M.L.; Calvo, C.; Rey, C.; Díaz, B.; Molinero, M.D.; Pozo, F.; Casas, I. Human metapnuemovirus infections in hospitalized children and comparison with other respiratory viruses. 2005-2014 prospective study. PLoS ONE 2017, 12, e0173504. [CrossRef]

18. Sung, R.Y.; Chan, P.K.; Tsen, T.; Li, A.M.; Lam, W.Y.; Yeung, A.C.; Nelson, E.A. Identification of viral and atypical bacterial pathogens in children hospitalized with acute respiratory infections in Hong Kong by multiplex PCR assays. J. Med. Virol. 2009, 81, 153-159. [CrossRef] 
19. Ruuskanen, O.; Lahti, E.; Jennings, L.C.; Murdoch, D.R. Viral pneumonia. Lancet 2011, 377, $1264-1275$. [CrossRef]

20. Tregoning, J.S.; Schwarze, J. Respiratory viral infections in infants: Causes, clinical symptoms, virology, and immunology. Clin. Microbiol. Rev. 2010, 23, 74-98. [CrossRef]

21. Thorburn, K.; Riordan, A. Pulmonary bacterial coinfection in infants and children with viral respiratory infection. Expert Rev. Anti Infect. Ther. 2012, 10, 909-916. [CrossRef] [PubMed]

22. McCullers, J.A. The co-pathogenesis of influenza viruses with bacteria in the lung. Nat. Rev. Microbiol. 2014, 12, 252-262. [CrossRef] [PubMed]

23. McCarthy, N.L.; Gee, J.; Sukumaran, L.; Weintraub, E.; Duffy, J.; Kharbanda, E.O.; Baxter, R.; Irving, S.; King, J.; Daley, M.F.; et al. Vaccination and 30-Day Mortality Risk in Children, Adolescents, and Young Adults. Pediatrics 2016, 137, e20152970. [CrossRef] [PubMed]

24. Marchisio, P.; Baggi, E.; Bianchini, S.; Principi, N.; Esposito, S. Clinical and socioeconomic impact of pediatric seasonal and pandemic influenza. Hum. Vaccin. Immunother. 2012, 8, 17-20. [CrossRef]

25. Principi, N.; Esposito, S. Influenza vaccine use to protect healthy children: A debated topic. Vaccine 2018, 28, 5391-5396. [CrossRef]

26. Esposito, S.; Principi, N. Influenza vaccination in pediatric age. Expert. Rev. Vaccines 2015, 14, 785-787. [CrossRef]

27. Antonova, E.N.; Rycroft, C.E.; Ambrose, C.S.; Heikkinen, T.; Principi, N. Burden of paediatric influenza in Western Europe: A systematic review. BMC Public Health 2012, 12, 968. [CrossRef]

28. Esposito, S.; Mencacci, A.; Cenci, E.; Camilloni, B.; Silvestri, E.; Principi, N. Multiplex Platforms for the Identification of Respiratory Pathogens: Are They Useful in Pediatric Clinical Practice? Front. Cell. Infect. Microbiol. 2019, 9, 196. [CrossRef]

29. Lafond, K.E.; Nair, H.; Rasooly, M.H.; Valente, F.; Booy, R.; Rahman, M.; Kitsutani, P.; Yu, H.; Guzman, G.; Coulibaly, D.; et al. Global role and burden of influenza in pediatric respiratory hospitalizations, 1982-2012: A systematic analysis. PLoS Med. 2016, 13, e1001977. [CrossRef]

30. Heikkinen, T.; Silvennoinen, H.; Heinonen, S.; Vuorinen, T. Clinical and socioeconomic impact of moderateto-severe versus mild influenza in children. Eur. J. Clin. Microbiol. Infect. Dis. 2016, 35, 1107-1113. [CrossRef]

31. Principi, N.; Esposito, S. Protection of children against influenza: Emerging problems. Protection of children against influenza: Emerging problems. Hum. Vaccin. Immunother. 2018, 14, 750-757. [CrossRef] [PubMed]

32. Principi, N.; Camilloni, B.; Esposito, S. ESCMID Vaccine Study Group (EVASG). Influenza immunization policies: Which could be the main reasons for differences among countries? Hum. Vaccin. Immunother. 2018, 14, 684-692. [CrossRef] [PubMed]

33. Paules, C.; Subbarao, K. Influenza. Influenza. Lancet 2017, 390, 697-708. [CrossRef]

34. Mistry, R.D.; Fischer, J.B.; Prasad, P.A.; Coffin, S.E.; Alpern, E.R. Severe complications in influenza-like illnesses. Pediatrics 2014, 134, 684-690. [CrossRef]

35. Nakamura, S.; Davis, K.M.; Weiser, J.N. Synergistic stimulation of type I interferons during influenza virus coinfection promotes Streptococcus pneumoniae colonization in mice. J. Clin. Investig. 2011, 121, 3657-3665. [CrossRef] [PubMed]

36. Opatowski, L.; Baguelin, M.; Eggo, R.M. Influenza interaction with cocirculating pathogens and its impact on surveillance, pathogenesis, and epidemic profile: A key role for mathematical modelling. PLoS Pathog. 2018, 14, e1006770. [CrossRef]

37. Principi, N.; Esposito, S. Severe influenza in children: Incidence and risk factors. Expert Rev. Anti Infect. Ther. 2016, 14, 961-968. [CrossRef]

38. Esposito, S.; Molteni, C.G.; Daleno, C.; Valzano, A.; Fossali, E.; Da Dalt, L.; Cecinati, V.; Bruzzese, E.; Giacchino, R.; Giaquinto, C.; et al. Clinical and socioeconomic impact of different types and subtypes of seasonal influenza viruses in children during influenza seasons 2007/2008 and 2008/2009. BMC Infect. Dis. 2011, 11, 271. [CrossRef]

39. Esposito, S.; Cantarutti, L.; Molteni, C.G.; Daleno, C.; Scala, A.; Tagliabue, C.; Pelucchi, C.; Giaquinto, C.; Principi, N. Clinical manifestations and socio-economic impact of influenza among healthy children in the community. J. Infect. 2011, 62, 379-387. [CrossRef]

40. Piralla, A.; Lunghi, G.; Ruggiero, L.; Girello, A.; Bianchini, S.; Rovida, F.; Caimmi, S.; Marseglia, G.L.; Principi, N.; Baldanti, F.; et al. Molecular epidemiology of influenza B virus among hospitalized pediatric patients in Northern Italy during the 2015-16 season. PLoS ONE 2017, 12, e0185893. [CrossRef] 
41. Esposito, S. 100 years since the 1918 influenza pandemic. Hum. Vaccin. Immunother. 2018, 14, 504-507. [CrossRef] [PubMed]

42. Chong, Y.; Ikematsu, $\mathrm{H}$. Is seasonal vaccination a contributing factor to the selection of influenza epidemic variants? Hum. Vaccin. Immunother. 2018, 14, 518-522. [CrossRef] [PubMed]

43. Treanor, J.J.; Talbot, H.K.; Ohmit, S.E.; Coleman, L.A.; Thompson, M.G.; Cheng, P.Y.; Petrie, J.G.; Lofthus, G.; Meece, J.K.; Williams, J.V.; et al. US Flu-VE Network. Effectiveness of seasonal influenza vaccines in the United States during a season with circulation of all three vaccine strains. Clin. Infect. Dis. 2012, 55, 951-959. [CrossRef] [PubMed]

44. Ferdinands, J.M.; Olsho, L.E.; Agan, A.A.; Bhat, N.; Sullivan, R.M.; Hall, M.; Mourani, P.M.; Thompson, M.; Randolph, A.G. Pediatric Acute Lung Injury and Sepsis Investigators (PALISI) Network. Effectiveness of influenza vaccine against life-threatening RT-PCR-confirmed influenza illness in US children, 2010-2012. J. Infect. Dis. 2014, 210, 674-683. [CrossRef] [PubMed]

45. Principi, N.; Senatore, L.; Esposito, S. Protection of young children from influenza through universal vaccination. Hum. Vaccin. Immunother. 2015, 11, 2350-2358. [CrossRef] [PubMed]

46. Centers for Disease Control and Prevention (CDC), Advisory Committee for Immunization Practices (ACIP). Recommended Child and Adolescent Immunization Schedule for Ages 18 Years or Younger, United States. 2019. Available online: https://www.cdc.gov/vaccines/schedules/hcp/imz/child-adolescent.html\#note-flu (accessed on 22 May 2019).

47. Grohskopf, L.A.; Sokolow, L.Z.; Broder, K.R.; Olsen, S.J.; Karron, R.A.; Jernigan, D.B.; Bresee, J.S. Prevention and Control of Seasonal Influenza with Vaccines; Recommendations and reports: Morbidity and Mortality Weekly Report; Centers for Disease Control and Prevention: Atlanta, GA, USA, 2016; Volume 65, p. 54.

48. Esposito, S.; Principi, N. European Society of Clinical Microbiology Infectious Diseases (ESCMID) Vaccine Study Group (EVASG). Influenza vaccination and prevention of antimicrobial resistance. Expert Rev. Vaccines 2018, 17, 881-888. [CrossRef] [PubMed]

49. Poehling, K.A.; Szilagyi, P.G.; Staat, M.A.; Snively, B.M.; Payne, D.C.; Bridges, C.B.; Chu, S.Y.; Light, L.S.; Prill, M.M.; Finelli, L.; et al. New Vaccine Surveillance Network. Impact of maternal immunization on influenza hospitalizations in infants. Am. J. Obstet. Gynecol. 2011, 204, 141-148. [CrossRef]

50. Eick, A.A.; Uyeki, T.M.; Klimov, A.; Hall, H.; Reid, R.; Santosham, M.; O’Brien, K.L. Maternal influenza vaccination and effect on influenza virus infection in young infants. Arch. Pediatr. Adolesc. Med. 2011, 165, 104-111. [CrossRef]

51. Nunes, M.C.; Cutland, C.L.; Jones, S.; Downs, S.; Weinberg, A.; Ortiz, J.R.; Neuzil, K.M.; Simões, E.A.F.; Klugman, K.P.; Madhi, S.A. Efficacy of Maternal Influenza Vaccination Against All-Cause Lower Respiratory Tract Infection Hospitalizations in Young Infants: Results from a Randomized Controlled Trial. Clin. Infect. Dis. 2017, 65, 1066-1071. [CrossRef]

52. Zaman, K.; Roy, E.; Arifeen, S.E.; Rahman, M.; Raqib, R.; Wilson, E.; Omer, S.B.; Shahid, N.S.; Breiman, R.F.; Steinhoff, M.C. Effectiveness of maternal influenza immunization in mothers and infants. N. Engl. J. Med. 2008, 359, 1555-1564. [CrossRef]

53. Esposito, S.; Bosis, S.; Morlacchi, L.; Baggi, E.; Sabatini, C.; Principi, N. Can infants be protected by means of maternal vaccination? Clin. Microbiol. Infect. 2012, 18, 85-92. [CrossRef] [PubMed]

54. Domenech, M.; Sempere, J.; de Miguel, S.; Yuste, J. Combination of Antibodies and Antibiotics as a Promising Strategy Against Multidrug-Resistant Pathogens of the Respiratory Tract. Front. Immunol. 2018, 9, 2700. [CrossRef] [PubMed]

55. Knight, G.M.; Clarkson, M.; de Silva, T.I. Potential impact of influenza vaccine roll-out on antibiotic use in Africa. J. Antimicrob. Chemother. 2018, 73, 2197-2200. [CrossRef] [PubMed]

56. Meek, R.W.; Vyas, H.; Piddock, L.J. Nonmedical Uses of Antibiotics: Time to Restrict Their Use? PLoS Biol. 2015, 13, e1002266. [CrossRef]

57. Ruf, B.R.; Knuf, M. The burden of seasonal and pandemic influenza in infants and children. Eur. J. Pediatr. 2014, 173, 265-276. [CrossRef]

58. Esposito, S.; Principi, N. Different influenza vaccine formulations and adjuvants for childhood influenza vaccination. Vaccine 2011, 29, 7535-7541. [CrossRef]

59. Principi, N.; Di Cara, G.; Bizzarri, I.; Isidori, C.; Borgia, P.; Mignini, C.; Saponara, M.; Argentiero, A.; Esposito, S. Prevention of Invasive Pneumococcal Disease: Problems Emerged after Some Years of the 13-Valent Pneumococcal Conjugate Vaccine Use. Curr. Infect. Dis. Rep. 2018, 20, 1. [CrossRef] 
60. Azzari, C.; Serranti, D.; Nieddu, F.; Moriondo, M.; Casini, A.; Lodi, L.; de Benedictis, F.M.; De Vitis, E.; Cavone, F.; Cortimiglia, M.; et al. Significant impact of pneumococcal conjugate vaccination on pediatric parapneumonic effusion: Italy 2006-2018. Vaccine 2019, 37, 2704-2711. [CrossRef]

61. Shigayeva, A.; Rudnick, W.; Green, K.; Chen, D.K.; Demczuk, W.; Gold, W.L.; Johnstone, J.; Kitai, I.; Krajden, S.; Lovinsky, R.; et al. Toronto Invasive Bacterial Diseases Network. Invasive Pneumococcal Disease Among Immunocompromised Persons: Implications for Vaccination Programs. Clin. Infect. Dis. 2016, 62, 139-147. [CrossRef]

62. Esposito, S.; Colombo, C.; Tosco, A.; Montemitro, E.; Volpi, S.; Ruggiero, L.; Lelii, M.; Bisogno, A.; Pelucchi, C.; Principi, N.; et al. Italian Pneumococcal Study Group on Cystic Fibrosis. Streptococcus pneumoniae oropharyngeal colonization in children and adolescents with cysticfibrosis. J. Cyst. Fibros. 2016, 15, 366-371. [CrossRef]

63. Esposito, S.; Principi, N. European Society of Clinical Microbiology and Infectious Diseases Escmid Vaccine Study Group Evasg1. Strategies to develop vaccines of pediatric interest. Expert Rev. Vaccines 2017, 16, 175-186. [CrossRef] [PubMed]

64. Black, S.; Shinefield, H.; Baxter, R.; Austrian, R.; Bracken, L.; Hansen, J.; Lewis, E.; Fireman, B. Postlicensure surveillance for pneumococcal invasive disease after use of heptavalent pneumococcal conjugate vaccine in Northern California Kaiser Permanente. Pediatr. Infect. Dis. J. 2004, 23, 485-489. [CrossRef] [PubMed]

65. Van Werkhoven, C.H.; Huijts, S.M. Vaccines to Prevent Pneumococcal Community-Acquired Pneumonia. Clin. Chest Med. 2018, 39, 733-752. [CrossRef] [PubMed]

66. Principi, N.; Esposito, S. Prevention of Community-Acquired Pneumonia with Available Pneumococcal Vaccines. Int. J. Mol. Sci. 2016, 18, E30. [CrossRef] [PubMed]

67. Mrkvan, T.; Pelton, S.I.; Ruiz-Guiñazú, J.; Palmu, A.A.; Borys, D. Effectiveness and impact of the 10-valent pneumococcal conjugate vaccine, PHiD-CV: Review of clinical trials and post-marketing experience. Expert Rev. Vaccines 2018, 17, 797-818. [CrossRef]

68. Esposito, S.; Principi, N. ESCMID Vaccine Study Group. Direct and indirect effects of the 13-valent pneumococcal conjugate vaccine administered to infants and young children. Future Microbiol. 2015, 10, 1599-1607. [CrossRef]

69. Principi, N.; Esposito, S. The impact of 10-valent and 13-valent pneumococcal conjugate vaccines on serotype 19A invasive pneumococcal disease. Expert Rev. Vaccines 2015, 14, 1359-1366. [CrossRef]

70. Esposito, S.; Principi, N. Pneumococcal immunization with conjugate vaccines: Are 10-Valent and 13-Valent vaccines similar? Future Microbiol. 2019, 921-923. [CrossRef]

71. Argondizo-Correia, C.; Rodrigues, A.K.S.; de Brito, C.A. Neonatal Immunity to Bordetella pertussis Infection and Current Prevention Strategies. J. Immunol. Res. 2019, 2019, 7134168. [CrossRef]

72. Principi, N.; Litt, D.; Terranova, L.; Picca, M.; Malvaso, C.; Vitale, C.; Fry, N.K.; Esposito, S. The Italian Pertussis Group for Persistent Cough in Children. Pertussis-associated persistent cough in previously vaccinated children. J. Med. Microbiol. 2017, 66, 1699-1702. [CrossRef]

73. Melvin, J.A.; Scheller, E.V.; Miller, J.F.; Cotter, P.A. Bordetella pertussis pathogenesis: Current and future challenges. Nat. Rev. Microbiol. 2014, 12, 274-288. [CrossRef] [PubMed]

74. Polinori, I.; Esposito, S. Clinical Findings and Management of Pertussis. Adv. Exp. Med. Biol. 2019. [CrossRef]

75. Esposito, S.; Principi, N. Prevention of pertussis: An unresolved problem. Hum. Vaccin. Immunother. 2018, 14, 2452-2459. [CrossRef] [PubMed]

76. Marcellini, V.; Piano, M.E.; Fedele, G.; Gesualdo, F.; Pandolfi, E.; Midulla, F.; Leone, P.; Stefanelli, P.; Tozzi, A.E.; Carsetti, R. Pertussis Study Group. Protection against Pertussis in Humans Correlates to Elevated Serum Antibodies and Memory B Cells. Front. Immunol. 2017, 8, 1158. [CrossRef] [PubMed]

77. Kauhl, B.; Heil, J.; Hoebe, C.J.; Schweikart, J.; Krafft, T.; Dukers-Muijrers, N.H. Is the current pertussis incidence only the results of testing? A spatial and space-time analysis of pertussis surveillance data using cluster detection methods and geographically weightedregression modelling. PLoS ONE 2017, 12, e0172383. [CrossRef] [PubMed]

78. Wilk, M.M.; Borkner, L.; Misiak, A.; Curham, L.; Allen, A.C.; Mills, K.H.G. Immunization with whole cell but not acellular pertussis vaccines primes CD4 TRM cells that sustain protective immunity against nasal colonization with Bordetella pertussis. Emerg. Microbes. Infect. 2019, 8, 169-185. [CrossRef]

79. World Health Organization. Pertussis vaccines: WHO position paper-August 2015. Wkly. Epidemiol. Record 2015, 90, 433-460. 
80. European Centre for Disease Prevention and Control. Vaccine Schedule. Pertussis. Available online: http://vaccine-schedule.ecdc.europa.eu/pages/scheduler.aspx (accessed on 22 May 2019).

81. Amirthalingam, G.; Andrews, N.; Campbell, H.; Ribeiro, S.; Kara, E.; Donegan, K.; Fry, N.K.; Miller, E.; Ramsay, M. Effectiveness of maternal pertussis vaccination in England: An observational study. Lancet 2014, 384, 1521-1528. [CrossRef]

82. Romanin, V.; Acosta, A.M.; Juarez, M.D.V.; Briere, E.; Sanchez, S.M.; Cordoba, B.L.; Sevilla, M.E.; Lucion, M.F.; Urrutia, A.; Sagradini, S.; et al. Maternal Vaccination in Argentina: Tdap Vaccine Effectiveness During Pregnancy in Preventing Pertussis in Infants Less Than 2 Months of Age. Clin. Infect. Dis. 2019, 16, 217.

83. Esposito, S.; Stefanelli, P.; Fry, N.K.; Fedele, G.; He, Q.; Paterson, P.; Tan, T.; Knuf, M.; Rodrigo, C.; Weil, O.C.; et al. World Association of Infectious Diseases and Immunological Disorders (WAidid) and the Vaccine Study Group of the European Society of Clinical Microbiology and Infectious Diseases (EVASG). Pertussis Prevention: Reasons for Resurgence, and Differences in the Current Acellular Pertussis Vaccines. Front. Immunol. 2019, 10, 1344.

84. Lancella, L.; Di Camillo, C.; Vittucci, A.C.; Boccuzzi, E.; Bozzola, E.; Villani, A. Measles lessons in an anti-vaccination era: Public health is a social duty, not a political option. Ital. J. Pediatr. 2017, 43, 102. [CrossRef] [PubMed]

85. Moss, W.J. Measles. Lancet 2017, 390, 2490-2502. [CrossRef]

86. CDC. Measles Cases and Outbreaks. Available online: https://www.cdc.gov/measles/cases-outbreaks.html (accessed on 22 May 2019).

87. ECDC. Monthly Measles and Rubella Monitoring Report, May 2019. Available online: https://ecdc.europa.eu/ en/publications-data/monthly-measles-and-rubella-monitoring-report-may-2019 (accessed on 22 May 2019).

88. Green, C.A.; Sande, C.J.; de Lara, C.; Thompson, A.J.; Silva-Reyes, L.; Napolitano, F.; Pierantoni, A.; Capone, S.; Vitelli, A.; Klenerman, P.; et al. Humoral and cellular immunity to RSV in infants, children and adults. Vaccine 2018, 36, 6183-6190. [CrossRef] [PubMed]

89. Esposito, S.; Piralla, A.; Zampiero, A.; Bianchini, S.; Di Pietro, G.; Scala, A.; Pinzani, R.; Fossali, E.; Baldanti, F.; Principi, N. Characteristics and Their Clinical Relevance of Respiratory Syncytial Virus Types and Genotypes Circulating in Northern Italy in Five Consecutive Winter Seasons. PLoS ONE 2015, 10, e0129369. [CrossRef] [PubMed]

90. Bosis, S.; Esposito, S.; Niesters, H.G.; Zuccotti, G.V.; Marseglia, G.; Lanari, M.; Zuin, G.; Pelucchi, C.; Osterhaus, A.D.; Principi, N. Role of respiratory pathogens in infants hospitalized for a first episode of wheezing and their impact on recurrences. Clin. Microbiol. Infect. 2008, 14, 677-684. [CrossRef]

91. Esposito, S.; Scarselli, E.; Lelii, M.; Scala, A.; Vitelli, A.; Capone, S.; Fornili, M.; Biganzoli, E.; Orenti, A.; Nicosia, A.; et al. Antibody response to respiratory syncytial virus infection in children $<18$ months old. Hum. Vaccin. Immunother. 2016, 12, 1700-1706.

92. Esposito, S.; Pietro, G.D. Respiratory syncytial virus vaccines: An update on those in the immediate pipeline. Future Microbiol. 2016, 11, 1479-1490. [CrossRef]

93. Behzadi, M.A.; Leyva-Grado, V.H. Overview of Current Therapeutics and Novel Candidates Against Influenza, Respiratory Syncytial Virus, and Middle East Respiratory Syndrome Coronavirus Infections. Front. Microbiol. 2019, 10, 1327. [CrossRef]

(C) 2019 by the authors. Licensee MDPI, Basel, Switzerland. This article is an open access article distributed under the terms and conditions of the Creative Commons Attribution (CC BY) license (http://creativecommons.org/licenses/by/4.0/). 